\title{
COMBATTING RACIST SPEECH: THE CANADIAN EXPERIENCE '
}

\author{
BRUCE P. ELMAN
}

This article traces a decade of Canadian jurisprudence on hate speech and Holocaust denial historical revisionism. It first compares the cases of Keegstra and Zundel and examines the constitutionality and efficacy of Criminal Code sections $319(2)$ and 181 as invoked in each case respectively. The article then examines alternative methods to the imposition of criminal sanctions for addressing the problem of hate propaganda. The cases of Malcolm Ross, John Ross Taylor and the Aryan Nations are reviewed in order to evaluate the use of human rights legislation to combat hate speech. The author concludes that while it is important for Canada 10 maintain criminal legislation, human rights legislation has some considerable advantages over criminal sanctions. Human rights hearings are less expensive, less timeconsuming, and less complicated than criminal proceedings. Further to this, the standard of proof is the civil standard of balance of probabilities, and intent $t o$ harm need not be proven as in a criminal trial. Finally, the author gives a reminder of the value of education as an effective method of both minimizing the credibility of the hate-monger's message, and decreasing the susceptibility of the public to such messages.
Dans le présent article, l'auteur examine une décennie de jurisprudence canadienne à l'égard des discours haineux et du néorévisionnisme. Il compare d'abord le cas de Keegstra et de Zundel, et étudie la constitutionnalité et l'efficacité des art. 319(2) et 181 du Code criminel invoqués, respectivement. II considère les mesures qui pourraient sanctionner le probleme de la propagande haineuse. Il évoque les cas de Malcolm Ross, de John Ross Taylor et des Aryan Nations pour évaluer le bien-fondé du recours à la législation sur les droits de la personne. L'auteur conclut que, bien qu'il soit important de maintenir le Code criminel, la législation sur les droits de la personne présente des avantages considérables sur les sanctions prévues pour les actes criminels. Elle donne lieu à des audiences moins coûteuses, moins longues et moins compliquées que les procédures criminelles. De plus, l'établissement de la preuve se fait au moyen d'une prépondérance de probabilités, et il $n$ 'est pas nécessaire de prouver l'intention de nuire, comme pour les actes criminels. Finalement. l'auteur rappelle l'importance de l'éducation, qui présente le double avantage de minimiser la crédibilité des messages haineux et la vulnérabilité du public à leur égard.

\section{TABLE OF CONTENTS}

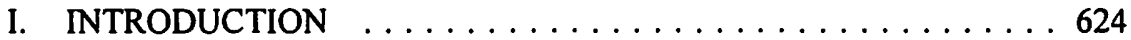

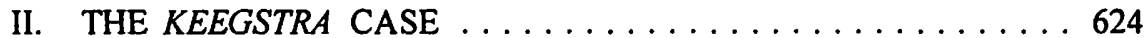

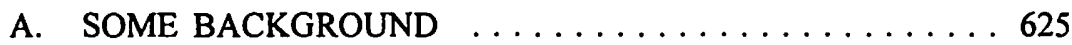

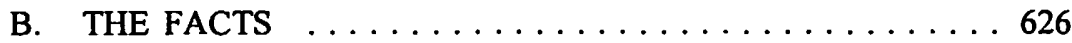

C. CASE HISTORY . . . . . . . . . . . . . . . 627

D. THE SUPREME COURT OF CANADA DECISION . . . . 627

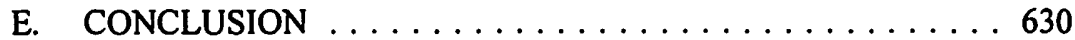

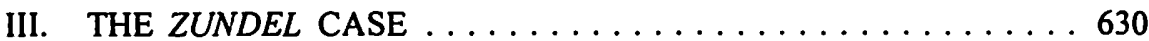

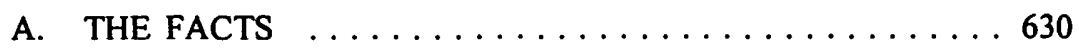

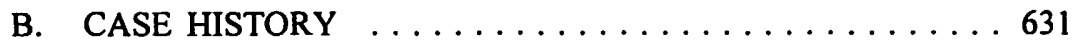

C. THE SUPREME COURT OF CANADA DECISION .... 632

D. DISSENTING JUDGMENT $\ldots \ldots \ldots \ldots \ldots \ldots \ldots 635$

Professor, Faculty of Law, and Chair, Centre for Constitutional Studies, University of Alberta. This paper was first delivered at a conference of the Society for the Reform of the Criminal Law entitled 100 Years of Criminal Codes, Ottawa, Ontario, June 1993. I am indebted to my research assistant Erin Nelson who assisted me in the preparation of this article. 
IV. ZUNDEL AND KEEGSTRA: A COMPARISON $\ldots \ldots \ldots \ldots 637$

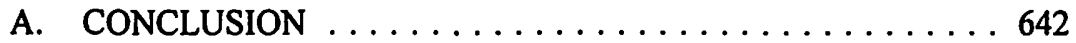

V. ALTERNATIVES TO CRIMINAL SANCTIONS: ROSS, TAYLOR AND THE ARYAN NATIONS $\ldots \ldots \ldots \ldots \ldots \ldots 44$

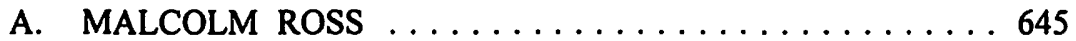

B. JOHN ROSS TAYLOR . . . . . . . . . . . . . . 649

C. THE ARYAN NATIONS $\ldots \ldots \ldots \ldots \ldots \ldots \ldots \ldots 63$

VI. CONCLUDING REMARKS $\ldots \ldots \ldots \ldots \ldots \ldots \ldots \ldots 66$

\section{INTRODUCTION}

Ten years ago, two women from the small town of Eckville, Alberta - Susan Maddox and Marg Andrew - joined forces to lay a complaint with the Lacombe County School Board about the subject matter being taught by one James Keegstra, a social studies and industrial arts teacher in the Eckville Junior and Senior High School.

This touched off a decade of litigation wherein Canadians have attempted, through various forensic means, to counter the harmful effects of hate propaganda and Holocaust denial historical revisionism. In attempting to eradicate racist speech, Canadians have seen teachers fired or removed from the classroom, the withdrawal of mailing privileges, customs and excise orders banning the importing of racist materials, injunctions under human rights acts (both federal and provincial) designed to prevent racist expression and displays, criminal prosecutions under three different Criminal Code provisions, and, finally, personal injury litigation.

The Canadian jurisprudential experience is therefore important for other countries as they search for ways to combat racism while still preserving freedom of speech. The names - James Keegstra, Ernst Zundel, John Ross Taylor, Malcolm Ross, Terry Long - are well-known in this country and abroad. They represent the signposts in Canada's decade-long struggle to produce a more tolerant and just society. Here, then, is the story of the past decade.

\section{THE KEEGSTRA CASE}

On January 11, 1984, James Keegstra, a teacher at the Junior and Senior High School in Eckville, Alberta, was charged with wilfully promoting hatred against the Jewish people contrary to what is now section 319(2) of the Criminal Code of Canada. ${ }^{2}$ The charge related to statements made by Keegstra while teaching his grades 9 and 12 Social Studies classes. The Keegstra prosecution heightened an already lively debate on whether the Criminal Code prohibition against the dissemination of hate propaganda was constitutionally valid. The debate raged on in the public forum and within our court system for almost seven years. Finally, on December 13, 1990, the Supreme Court of Canada settled the matter, for the time being at least: the Justices, by a four to three majority, upheld the constitutional validity of section $319(2){ }^{3}$ 


\section{A. SOME BACKGROUND}

In 1965, the Minister of Justice, the Honourable Guy Favreau, set up a special committee to study the problem of hate propaganda in Canada. The committee, chaired by Dean Maxwell Cohen of McGill Law School, concluded that the provisions of the Criminal Code were inadequate to deal with the problems of hate propaganda. Consequently, the committee recommended amendments to the Criminal Code which would put in place provisions to deal with the various aspects of hate propaganda. The Cohen Committee suggested that Parliament enact prohibitions against the "advocating of genocide" (now section 318), the "public incitement of hatred" (now section 319(1)), and the "wilful promotion of hatred" (now section 319(2)). Special search and seizure powers relating to hate propaganda (now section 320) were also recommended. These recommendations were adopted by Parliament and became law in 1970 .

From the outset, the most controversial of these provisions was the prohibition against the "wilful incitement of hatred." The text of the provision is as follows:

Everyone who, by communicating statements, other than in private conversation, wilfully promotes hatred against any identifiable group is guilty of

(a) an indictable offence and is liable to imprisonment for two years; or

(b) an offence punishable on summary conviction.

Even in the years before Canadian Charter of Rights and Freedoms ${ }^{4}$ came into effect, critics complained that the provision was an infringement of freedom of expression. This criticism, quite naturally, intensified after the advent of the Charter. From the outset, the Cohen Committee had been sensitive to this criticism. In order to allay the fears of civil libertarians, the Committee made two suggestions: (1) that no prosecutions should be undertaken without the consent of the Attorney General, and (2) that a set of defences specifically designed to narrow the scope of the prohibition against the "wilful incitement of hatred" be included in the Criminal Code. These defences are found in section 319(3):

No person shall be convicted of an offence under subsection (2)

(a) if he established that the statements communicated were true;

(b) if, in good faith, he expressed or attempted to establish by argument an opinion on a religious subject;

(c) if the statements were relevant to any subject of public interest, discussion of which was for the public benefit, and if on reasonable grounds he believed them to be true;

Part I of the Constitution Act, 1982, being Schedule B to the Canada Act 1982 (U.K), 1982, c. 11 [hereinafter Charter]. 
if, in good faith, he intended to point out, for the purpose of removal, matters producing or tending to produce feelings of hatred towards an identifiable group in Canada.

Not only was this provision unsatisfactory to civil libertarians, it engendered a different type of criticism from those minority ethnic and religious groups who had lobbied so strenuously for the adoption of the Cohen Committee recommendations. Their criticism was straightforward: the provisions were unworkable. The combined effect of sections 319(2) and (3) would make it impossible to convict anyone of this offence. They pointed to the numerous requirements for conviction:

(1) The Crown must prove that the accused's conscious purpose was to promote hatred. The accused may accidentally, negligently, or even recklessly promote hatred. This is not a crime. It is only the wilful or intentional promotion of hatred which is prohibited.

(2) This wilful promotion of hatred must be directed towards an identifiable group. An identifiable group is one that is distinguishable by colour, race, religion, or ethnic origin.

(3) The statements which promote hatred must be other than in private conversation.

(4) The Crown must prove beyond a reasonable doubt that the accused was not making a good faith argument on a religious subject.

(5) Further, the Crown must disprove, also beyond a reasonable doubt, any reasonable "mistaken belief" defence.

(6) Finally, the Crown must prove beyond a reasonable doubt that the accused was not, in good faith, attempting to point out, for the purpose of removal, matters tending to produce feelings of hatred.

(7) The accused may still escape conviction if he proves that the statements he made were true.

It is little wonder that the leadership of the various ethnic and religious communities in Canada saw the provisions as unworkable. And the Attorneys-General of the provinces, whose task it is to prosecute under the law, agreed with them.

\section{B. THE FACTS}

James Keegstra began his teaching career as an industrial arts teacher. He showed an "interest" in history and soon found himself teaching Social Studies 9 and 30 (Grades 9 and 12 history, respectively). The curriculum of Social Studies 30 was supposed to be an examination of world history since 1900. Keegstra, however, was not constrained by this "technicality". 
He taught that all the major events of history were connected to one central theme: a Jewish conspiracy to take over the world and rule it through the mechanism of one world government. He taught that the Jews were responsible for the First and Second World Wars. He linked the Jewish people to the American, French and Russian Revolutions. He taught that Jews formed secret societies - the Jacobins, the Illuminati, the Bolsheviks - to pursue their evil plan to rule the world. He taught that Jews controlled the government, the banks, the courts, and the media. And he taught that the Holocaust was a hoax. He taught that the Talmud was the "blueprint" for this one world government. For confirmation of his views, he pointed to the New Testament.

Keegstra taught his students by lecturing. He would speak and they would write down his words. Sometimes he would write a phrase on the blackboard for emphasis and the students knew that this was important (i.e. that it should be used on an exam or in an essay) and they would copy it down in their notebooks. Students were evaluated on essays, tests, and exams. The students were to rely on their notes to complete these assignments. Other, more "mainstream" material was not to be used. History books, encyclopedias, and the like were "censored history" and their use was discouraged.

\section{CASE HISTORY}

Keegstra was charged under S. 319(2) of the Criminal Code in January 1984. The preliminary hearing took place in June 1984. The accused was bound over for trial. In October 1984 - prior to the trial - a hearing to examine the constitutionality of the Criminal Code provision was held. A decision upholding the validity of the provision was delivered the next month. The trial began in April 1985 and lasted three and onehalf months. Keegstra was on the stand for one of those months, during which he quoted extensively from, among other things, biblical scripture. The jury found Keegstra guilty and he was ordered to pay a fine of $\$ 5,000$. Keegstra appealed. On June 6,1988 , the Alberta Court of Appeal overturned his conviction on the basis that section 319(2) was unconstitutional. The Crown appealed to the Supreme Court of Canada and the argument was heard in December 1989. One year later, the Supreme Court of Canada granted the Crown appeal, declaring section 319(2) to be constitutionally valid. For the time being, Keegstra's conviction was reinstated, but the Court returned the matter to the Alberta Court of Appeal for reargument on questions involving the conduct of the trial. On March 15, 1991, the Alberta Court of Appeal ordered a new trial. The Court was of the view that the method of jury selection was defective. A second trial was held and Keegstra was convicted once again. He was sentenced to pay a fine of $\$ 3,000$. He has appealed his second conviction and a decision is pending. It has been over ten years since the original information was laid and the case has not yet been concluded. More about this aspect of the case later.

\section{THE SUPREME COURT OF CANADA DECISION}

Keegstra's challenge to the constitutional validity of section 319(2) was based upon section 2(b) of the Charter, which provides: 
Everyone has the following fundamental freedoms:

(b) freedom of thought, belief, opinion and expression, including freedom of the press and other media of communication;

In their analysis, both the majority and the dissent followed the now-standard twostage approach to Charter adjudication. First, each examined whether section 319(2) of the Criminal Code violated section 2(b) of the Charter. The majority opinion asserted the proposition that expression which "wilfully promotes hatred" does not fall outside the protection of section 2(b) of the Charter. Any activity which attempts to convey meaning through a non-violent form of expression has expressive content and falls within the scope of section 2(b). ${ }^{5}$ Further, they held that hate propaganda was not analogous to violence and, consequently, no exception for hate propaganda could be carved out of the protection afforded by section 2(b) of the Charter. ${ }^{6}$

The argument that section 2(b) had to be interpreted in light of sections 15 (equal protection) and 27 (preservation of multiculturalism) of the Charter, as well as our International instruments and agreements, was rejected by the majority. Sections of the Charter, other than section 2(b), and International instruments and agreements could not be used to attenuate the scope of the protection afforded by freedom of expression under the Charter. These contextual values and factors should be used in the second phase of the inquiry - the justification stage.

The dissent was in general agreement with the majority in this stage of the analysis.

In the second phase, the "section 1 test", the Court examined whether section 319(2) was a reasonable limit which was demonstrably justified in a free and democratic society. The divergence of views between majority and dissenting factions of the Court rests, as it often does, on the result of the stage two analysis: the majority finds section 319(2) a reasonable and justifiable limitation; the dissent does not. Section 1 of the Charter provides:

The Canadian Charter of Rights and Freedoms guarantees the rights and freedoms set out in it subject only to such reasonable limits prescribed by law as can be demonstrably justified in a free and democratic society.

In dealing with the s. 1 inquiry, the Court followed the now familiar test as set out in $R$. v. Oakes: ${ }^{7}$

1. The provision must address a legislative objective which is sufficiently important to warrant overriding a constitutional right. The objective of the legislation must be pressing and substantial.

2. The means used to achieve the objective must be proportional:

s Even threats of violence, according to the majority, would fall within s. 2(b). See Keegstra, supra note 3 at 731-733.

Ibid. at 732 .

R. v. Oakes, [1986] I S.C.R. 103 [hereinafter Oakes]. 
(i) the means must be rationally connected to the objective;

(ii) the means must impair the Charter right or freedom as little as possible;

(iii) the effect of the means must be proportional to the legislative objective.

The majority began by noting that the objective - preventing pain to the target group and reducing racial, ethnic, and religious tension and, perhaps, violence - was of sufficient importance to warrant overriding a guaranteed right. Canada's international obligations and Charter sections 15 and 27 emphasize the importance of this objective. Furthermore, in the majority's opinion, section $319(2)$ is a reasonable and proportional response to secure that objective: the Code provision is rationally connected to the objective and does not unduly impair freedom of expression. On this latter point, the majority noted that section 319(2) was not vague nor was it overly broad. Indeed, in the majority's view, the Code section was narrowly drawn. They pointed to many of the requirements for a successful prosecution noted above. Other methods, non-criminal in nature, may exist for combatting racist incitement but Parliament is not limited to only one of these methods. Occasionally, the majority noted, condemnation through the force of the criminal law will be necessary. ${ }^{8}$

Finally, the majority held that the advantages of the prohibition against racist incitement outweighed any resulting harmful effects. Once again, the majority referred to the importance of the protection of equality, the preservation and enhancement of multiculturalism, and Canada's international obligations. They contrasted this with the fact that hate propaganda is only tenuously related to the values underlying freedom of expression: the search for truth, individual self-fulfilment, and the maintenance of a vibrant democracy. ${ }^{9}$ Thus, the majority upheld the constitutional validity of section 319(2) of the Criminal Code and reinstated Keegstra's conviction at least until the Alberta Court of Appeal could adjudicate on other issues involving the conduct of the trial.

The dissent, while agreeing that the objective was an important one, ${ }^{10}$ disagreed on whether section 319(2) was a reasonable and proportional means of securing the objective. They were of the view the Code section was not rationally connected to the objective: there was no evidence that criminalizing the dissemination of hate propaganda would, in fact, suppress it. Indeed, the dissent noted that criminalizing racist incitement might have the reverse effect of promoting racism by providing greater publicity and exposure for the racist propaganda." Further, the dissent held that section 319(2) was overly broad in that it could potentially catch more expression than was justifiable. ${ }^{12}$ In any event, the provision has a chilling effect on legitimate public discourse. They noted that alternative methods, less intrusive than prohibiting racist

Supra note 3 at 785.

Ibid. at 787.

Ibid. at 847.

Ibid. at 852-854.

Ibid. at 855. 
incitement, are available to Parliament. ${ }^{13}$ Given the serious potential damage to freedom of expression and the dubious benefit to be gained from prohibiting the dissemination of hate propaganda, the dissent held that section 319(2) was not a justifiable limit on freedom of expression and was of no force or effect.

\section{E. CONCLUSION}

Although the Court held that section 319(2) of the Criminal Code was valid, the strength of support for the constitutional validity of section 319(2) could be described as "soft".

Two of the four Supreme Court Justices who voted to support the constitutional validity of section 319(2) retired from the Court shortly thereafter. One, Chief Justice Dickson, was replaced in the Supreme Court by Justice Stevenson who, as a member of the Alberta Court of Appeal, had voted to strike down the hate propaganda law. Justice Stevenson has since left the Court. A second, Justice Wilson, was replaced by Justice Iacobucci whose views on this subject were not known. On the other hand, Justice Cory took no part in the decision. While a member of the Ontario Court of Appeal, Justice Cory had written a stirring judgement in support of the constitutionality of section 319(2) of the Code. ${ }^{14}$ Thus, we can safely assert that he would have sided with the majority. Justice Lamer (as he was then) also took no part in the decision. Although he has often sided with Justices Dickson and Wilson, his precise views on this subject were unknown.

Although it was unlikely that these changes in Court personnel would have resulted in an immediate overturning of the Keegstra decision itself, they may have had some effect in $R$. v. Zundel, which was heard shortly thereafter by the Court.

\section{THE ZUNDEL CASE}

\section{A. THE FACTS}

In 1984, Ernst Zundel, a cọmmercial artist living in Toronto, was charged with two counts of spreading false news contrary to s. 181 (formerly s. 177) of the Criminal Code. Section 181 of the Criminal Code provides:

Every one who wilfully publishes a statement, tale or news that he knows is false and that causes or is likely to cause injury or mischief to a public interest is guilty of an indictable offence and liable to imprisonment for a term not exceeding two years.

The charges arose from the publication of two articles: The West, War and Islam! and Did Six Million Really Die? The former was not distributed in Canada and Zundel was, consequently, acquitted of the charge pertaining to it. 
Did Six Million Really Die? was a thirty-two page pamphlet which was ostensibly written by Richard Harwood of the University of London, although the actual author of the piece was Richard Verral, then editor of a British neo-Nazi newspaper. Zundel had added a foreword and an afterword to the document. This pamphlet asserted that the Holocaust did not occur, that there was never an official Nazi policy of extermination of the Jews and other non-aryan peoples, and that allegations regarding the Holocaust are not "merely ... exaggeration, but an invention of post-war propaganda."15 The pamphlet went on to characterize the Holocaust as "the most colossal piece of fiction and the most successful of deceptions...." ${ }^{16}$

Further, the pamphlet alleged that Nazi concentration camps were only work camps and that the Russians built the gas chambers following the end of the Second World War. Several other false allegations were made in the document, including the assertion that The Diary of Anne Frank ${ }^{17}$ was a work of fiction. Zundel's defence at trial was that he had an honest belief in the truth of the work. This defence was not accepted by the jury and he was convicted and sentenced to fifteen months imprisonment and three years probation. During the probation period, he was not to publish anything on the subject of the Holocaust.

\section{B. CASE HISTORY}

\section{The First Appeal}

The trial judgment was appealed, on numerous grounds, to the Ontario Court of Appeal. In its decision, released on January 23, 1987, the Court overturned the verdict and ordered a new trial because of errors in the conduct of the trial. ${ }^{18}$ Only the Court's discussion of the constitutional issue has relevance here.

The constitutional issue considered by the Court was whether s. 181 violated s. 2(b) of the Canadian Charter of Rights and Freedoms: the guarantee of freedom of expression. The Court first examined the origin and history of the Code provision, dating back to De Scandalis Magnatum in 1275. This offence was primarily aimed at protecting "the peers and other great men against slanderous lies which might cause mischief to the public if the perpetrator were not punished." ${ }^{19}$ These statutes were repealed in England in 1888, but nonetheless the offence found its way into the draft Criminal Code of 1892. Until the 1955 amendments of the Code, the offence was listed under "Part VII: Seditious Offences, Title II: Offences Against Public Order, Internal and External". In 1955, the section (then s. 166) was moved into "Part IV: Sexual Offences, Public Morals and Disorderly Conduct", under the sub-heading of "Nuisances".

Did Six Million Really Die? at 4.

Ibid.

Anne Frank (1929-1945) was the teenage author of a diary composed while hiding from Nazis in Amsterdam. She died in Bergen Belsen concentration camp in 1945. The diary, discovered by nonJewish friends after the family's arrest, was first published in 1947. (Encyclopedia Judaica) R. v. Zundel (1987), 58 O.R. (2d) 129 (Ont. C.A.). Ibid. 
The Ontario Court of Appeal held that the expression prohibited by s. 181 (wilful assertions of fact(s) which are false to the knowledge of the person who publishes them, and which cause or are likely to cause injury or mischief to the public interest) did not fall within the protected sphere of freedom of expression. The Court further held that even if their decision with regard to s. 2(b) was erroneous and s. 181 did violate the guarantee of freedom of expression, the section would still be valid as a reasonable limit "prescribed by law as can be demonstrably justified in a free and democratic society" (s. 1 of the Charter).

This ground of appeal thus failed and the section was held to be constitutionally valid. Nonetheless, because of errors made by the trial judge, particularly with respect to jury selection and misdirection on elements of the offence, the conviction was quashed and a new trial ordered. The Supreme Court of Canada dismissed an application for leave to appeal from the Ontario Court of Appeal judgment. ${ }^{20}$

\section{The Second Trial}

A new trial was held, and on May 13,1988, a second jury delivered a guilty verdict. ${ }^{21}$ Ontario District Court Judge Thomas sentenced Zundel to nine months imprisonment. Zundel did not give evidence at this trial, as he had in the first trial. Judge Thomas stated that the sentence was less severe than that given at the first trial because there was "no evidence that the accused had actually been able to have any significant part of the community react to his beliefs." ${ }^{22}$

\section{The Second Appeal}

Zundel also appealed the second trial verdict, both in regard to his conviction and his sentence. The appeal judgment was released on February 5, 1990, but no discussion of the constitutionality of $\mathrm{s} .181$ was included.

\section{THE SUPREME COURT OF CANADA DECISION}

On November 15, 1990, the Supreme Court of Canada granted leave to appeal only with respect to the Charter issue: whether s. 181 of the Criminal Code was constitutionally valid. ${ }^{23}$ Although the constitutional questions involved challenges based upon both ss. 2(b) (freedom of expression) and 7 (fundamental justice) of the Charter, only the s. 2(b) issue was discussed in the majority opinion.

As noted earlier, Charter litigation usually involves a two-step process: (i) Does the statutory provision violate a Charter right? and (ii) Is it a justifiable limitation under s. 1 of the Charter? 


\section{Violation of the Right}

Is s. 181 of the Criminal Code a violation of s. 2(b) of the Charter? This involves two inquiries as posed earlier in the Irwin Toy case: ${ }^{24}$

(i) Is the prohibited expression protected by s. 2(b)? Does it attempt to convey meaning? Is it violent in form?

(ii) Is the purpose or effect of the government action in question (in this case $s$.

181) to restrict such expression?

In resolving this issue, Justice McLachlin reviewed the prior jurisprudence on freedom of expression. She noted that, in Irwin Toy, the Court held that s. 2(b) protected "minority beliefs which the majority regard as wrong or false"25 and that the Keegstra case stood for the proposition that content is irrelevant in determining whether or not expression is protected. All expressive activity is protected by s. 2(b) unless it is violent in form. ${ }^{26}$ The Court refused to concede the Crown's argument that lies or false statements can never have any value and therefore should not be protected by $s$. 2(b). Justice McLachlin stated that what is "false" cannot be defined with enough precision "to make falsity a fair criterion for denial of constitutional protection." 27

The Court held that the type of speech prohibited by s. 181 fell within the protected sphere of s. 2(b) and that the purpose and effect of s. 181 was to suppress such speech. Thus, the Court held that s. 181 was a violation of the constitutional guarantee of freedom of expression.

\section{Section 1 Analysis}

In determining whether section 181 is a reasonable and justifiable limitation on freedom of expression, the Court employed the Oakes test, just as they had done in Keegstra. ${ }^{28}$

First, in examining the legislative objective, Justice McLachlin found that there was no real evidence available as to the purpose or objective underlying $\mathrm{s}$. 181 . The original purpose of the false news provision was the preservation of "political harmony". However, in removing the section from that part of the Code entitled "Sedition" and placing it in the part entitled "Nuisance", Parliament seemed to have departed from the original political purpose of s. 181. Justice McLachlin rejected the suggestion that the purpose of s. 181 had become the preservation of "social harmony", as this was a "shifting purpose" which, in her opinion, was not constitutionally permissible. 
According to Justice McLachlin, the Court must look to the intent of the legislature at the time of the enactment or amendment of the relevant section. She noted that the Court "cannot assign objectives, nor invent new ones according to the perceived current utility of the impugned provision...." 29 Thus, she concluded that "Parliament (had) identified no social problem, much less one of pressing concern, justifying s. 181 of the Criminal Code. ${ }^{130}$

To bolster her argument that no pressing and substantial objective could be ascribed to s. 181, Justice McLachlin noted that, in 1986, the Law Reform Commission of Canada had recommended the repeal of s. 181, as it was "anachronistic". ${ }^{31}$ Furthermore, no other "free and democratic" countries had provisions similar to s. 181. As to some provisions alluded to by the dissent, the majority noted that these sections were all far more specific than $\mathbf{s . 1 8 1}$ and, in fact, appeared to be more comparable to s. 319(2) of the Code (wilful promotion of hatred) than to s. 181 .

Finally, the section has been used infrequently since 1955 . This lent further support to the argument that no legislative objective important enough to warrant overriding a Charter right could be attributed to s. 181. Justice McLachlin stated that the "purpose" branch of the Oakes test had not been met by s. 181. She further stated that even if s. 181 did have a valid and important legislative objective (as had been argued by the dissent), it would still fail under $s .1$ because it could not meet the proportionality test.

Although the majority found no articulated objective underlying s. 181, let alone one that was pressing and substantial, for the sake of the analysis they assumed that the section was rationally connected to the objective of "promoting social harmony." The majority proceeded to undertake the rest of the proportionality test.

Justice McLachlin held that the section was not a minimal impairment of the guarantee of freedom of expression. In her opinion, the "fatal flaw" of s. 181 was its overbreadth, particularly in relation to the "undefined and virtually unlimited reach of the phrase 'injury or mischief to a public interest'.".32

Justice McLachlin distinguished s. 181 from s. 319(2) by contrasting the term "hatred against any identifiable group" with "mischief to a public interest," which she asserted was "capable of almost infinite extension." ${ }^{33}$ The two sections were further distinguished in that s. 319(2) was restricted to the prohibition of hate propaganda, while s. 181 was not limited in this manner and could, therefore, affect a "broad spectrum of speech, much of which may be argued to have value.."34 Justice McLachlin also mentioned that while the expression at issue in the case at bar was

Ibid. at 774.

Ibid.

Jbid. at 775. 
arguably of little or negative value, the issue before the Court was the value of all expression which could potentially come within the reach of s. 181.

Although there was agreement among all members of the Court as to the potential harm which could result from the appellant's publications, in the result, the Supreme Court of Canada struck down s. 181 of the Criminal Code as a violation of s. 2(b) of the Charter which could not be upheld as a reasonable limit under s. 1, and entered an acquittal for Zundel.

\section{DISSENTING JUDGMENT}

Justices Cory and Iacobucci delivered dissenting reasons with Justice Gonthier concurring. In the dissent's view, s. 181 of the Criminal Code, although a violation of the freedom of expression guarantee in s. 2(b) of the Charter, was justified as a reasonable limit under s. 1 . The divergence between the majority and dissenting views turns, as it so often does, on the s. 1 analysis.

\section{Section 1 Analysis}

The dissent concluded that the aim of s. 181 was "to prevent the harm caused by the wilful publication of injurious lies" which "in turn promotes the public interest in furthering racial, religious and social tolerance. ${ }^{135}$ To support the importance of this objective, other Charter provisions were used, as were international instruments and "legislative responses in other jurisdictions. ${ }^{136}$

The International Convention on the Elimination of All Forms of Racial Discrimination, ${ }^{37}$ the International Covenant on Civil and Political Rights, ${ }^{38}$ and similar instruments were cited by the dissent "to emphasize the important objective of s. 181 in preventing the harm caused by calculated falsehoods which are likely to injure the public interest in racial and social tolerance." ${ }^{39}$

Sections 15 (equal protection) and 27 (enhancement of multicultural heritage) of the Charter were also employed by the dissent in an attempt to support the importance of s. 181 's objective.

The dissent concluded that $\mathrm{s} .181$ limited "only that expression which is peripheral to the core rights protected by s. 2(b). ${ }^{140}$ According to the dissent: 
[a] careful examination of the philosophical underpinnings of our commitment to free speech reveals that prohibiting deliberate lies which foment racism is mandated by a principled commitment to fostering free speech values. ${ }^{41}$

The dissent further held that they were bound to follow the Keegstra decision and, thus, it was "appropriate to limit expression protected by s. 2(b) under s. 1 where such expression threatens the dignity of members of the target group and promotes discrimination...." ${ }^{\text {42 }}$

Once the dissent had identified the objective of s. 181 as the promotion of "social harmony", they had little difficulty in finding that s. 181 met the "rational connection" branch of the proportionality test.

In the "minimal impairment" component of the s. 1 analysis, the dissent began with an examination of the text of s. 181. The dissent argued that $s .181$ was a "minimal intrusion" on freedom of expression because of the very heavy onus placed on the Crown in order to obtain a conviction. The Crown was required to prove: (i) the wilful publication of false factual statement(s) that the publisher knew were false and (ii) that the statement caused or was likely to cause injury to a public interest. All of these requirements were in an accused's favour, resulting in only a trivial encroachment on the s. 2(b) guarantee of freedom of expression.

In the majority decision, Justice McLachlin had identified the main defect in s. 181 as being overbreadth. The dissent argued that $\mathrm{s}$. 181 was not overly broad. In making this argument, the dissent had to overcome the difficulty presented by the text and, in particular, by the phrase "cause or are likely to cause injury to a public interest." No restriction on the meaning of the phrase "injury or mischief to a public interest" is found in the section. Numerous interpretations of the phrase are available to a trier of fact and thus there is potential for abuse.

Finally, in spite of the existence of hate propaganda legislation (Criminal Code s. 319(2)) the dissent held that s. 181 "still fulfils an important role in a multicultural and democratic society ... (in emphasizing) the repugnance of Canadian society for the wilful publication of known falsehoods that cause injury to the public interest through their attacks upon groups identifiable under s. 15 of the Charter...." 43

The dissent held that, given the minimal worth of the expression caught by $\mathbf{s .} 181$ and the narrow definition of the section, the effects of the section did not outweigh Parliament's objective. Once again, this analysis turns on the validity of the dissent's earlier decision that the promotion of "racial harmony" is a pressing and substantial objective underlying s. 181 . 
Although the reasons of the dissent are compelling, they are based on errors. The dissenting justices appear to have been motivated by grave concern with regard to the type of expression at issue in this particular case: Holocaust denial literature "disguised as authentic research. ${ }^{144}$

\section{ZUNDEL AND KEEGSTRA: A COMPARISON}

Zundel and the earlier case of $R$. v. Keegstra ${ }^{45}$ both involved the dissemination of anti-semitic propaganda. As noted earlier, Ernst Zundel was originally convicted under s. 181 of the Code for publishing and distributing Holocaust denial literature, while James Keegstra was convicted of wilfully promoting hatred contrary to s. 319(2) of the Criminal Code for "systematically denigrating Jews and Judaism" in his classes. While s. 181 was struck down as an infringement of s. 2(b) of the Charter that could not be saved by s. 1, the Supreme Court of Canada had earlier upheld s. 319(2) as constitutionally valid. Both provisions were found to infringe freedom of expression; the difference in the results arises from the $s .1$ analyses.

The two provisions are located in different parts of the Code; s. 181 is found under the heading of "Nuisance", while s. 319(2) is found in the "Hate Propaganda" section. Other differences include:

(1) Section 181 prohibits wilfully publishing a false statement tale or news; the content of a statement which may be prohibited is not specifically discussed in the provision. There is no indication as to whether Parliament's intention was to prohibit any particular type of statement, tale or news (for example, racist speech), but rather the section appears to have been designed to catch every false statement uttered.

(2) Further, the section speaks of mischief or injury to the public interest, but nowhere in the provision is this ambiguous phrase defined. The section is not clear on exactly what type of injury or mischief it seeks to prohibit or prevent; the public interest could be defined in innumerable ways.

(3) Section 319(2), on the other hand, explicitly deals with the wilful promotion of hate against identifiable groups. "Identifiable group" is defined as "any section of the public distinguished by colour, race, religion, or ethnic origin." ${ }^{46}$ Thus, the section is directed at preventing the growth of hate against vulnerable minorities.

(4) Arguably, s. 181 can apply to the publication of a false statement to only one other person. The definition of "publish" used in defamation law is that a statement has been published if it has been communicated to one person other 
than the one to whom the statement refers. Section 319(2), on the other hand, specifically exempts private conversation from its scope.

(5) Section 319(3) provides for statutory defences, further clarifying the narrow reach of the provision. Specific statutory defences are not found in $\mathrm{s} .181$.

(6) No prosecution under s. 319(2) can be commenced without consent of the Attorney-General. ${ }^{47}$ Under s. 181 , anyone may commence a prosecution.

As noted earlier, the difference in result lies in the outcome of the s. 1 analysis. The textual differences of the provisions appears to have been a major factor in the contrasting assessments of their respective provisions' constitutional validity.

\section{Section 1 Analysis}

The first step in the $s .1$ inquiry is a determination of whether the provision is based upon a legislative objective which is sufficiently important to override a Charter right. In the Zundel case, as noted earlier, the majority of the Court (per Justice McLachlin) had considerable difficulty in attributing any purpose to s. 181, let alone a "pressing and substantial" one.

In Keegstra, on the other hand, Chief Justice Dickson was able to define the objective of s. 319(2) as the prevention of harm caused by expression which promotes hatred of identifiable groups. The finding that this was, in fact, the objective of the section was supported by the "close connection between the recommendations of the Cohen Committee [which created the "Report of the Special Committee on Hate Propaganda in Canada"] and the hate propaganda amendments to the Criminal Code...." ${ }^{\text {48 }}$ Chief Justice Dickson identified the two principal harmful effects of hate propaganda as: (i) the response of humiliation and degradation engendered in members of the target group; and (ii) the influence such material has on society as a whole by indirectly causing attitudinal changes.

The objective attributed to s. 319(2) was further supported by our obligations under international human rights instruments such as the International Convention on the Elimination of All Forms of Racial Discrimination ${ }^{49}$ and the International Covenant on Civil and Political Rights, ${ }^{50}$ as well as by other sections of the Charter.

In reviewing other Charter provisions, Chief Justice Dickson focused on ss. 15 and 27, stating that those sections "represent a strong commitment to the values of equality and multiculturalism, and hence underline the great importance of Parliament's 
objective in prohibiting hate propaganda." 51 The conclusion reached by the Chief Justice with respect to the objective of s. 319(2) of the Criminal Code was that:

it would be impossible to deny that Parliament's objective in enacting s. 319(2) is of the utmost importance. Parliament has recognized the substantial harm that can flow from hate propaganda, and in trying to prevent the pain suffered by target group members and to reduce racial, ethnic and religious tension in Canada, has decided to suppress the wilful promotion of hatred against identifiable groups. $^{52}$

In Zundel, there is little reference to the "rational connection" branch of the s. 1 justification test. In the Keegstra decision, as noted earlier, Chief Justice Dickson first discussed the "relation of the expression at stake to free expression values" 53 and concluded that "expression intended to promote the hatred of identifiable groups is of limited importance when measured against free expression values." ${ }^{44}$ This finding allowed the Court to more easily justify s. 319(2) as a reasonable limit on freedom of expression.

In terms of whether s. 319(2) was rationally connected to Parliament's objective, the Chief Justice stated:

[I]t would be difficult to deny that the suppression of hate propaganda reduces the harm such expression does to individuals who belong to identifiable groups and to relations between various cultural and religious groups in Canadian society. 55

The Court did not accept the contention that the media coverage of a trial was likely to lead to an increased following for the hate-monger. Although media attention is often focused on the proceedings pursuant to charges under s. 319(2), the message sent by the publicity, as well as by the trial process, is "the severe reprobation with which society holds messages of hate directed towards racial and religious groups." 56

As to the contention that government suppression of expression would serve only to make that expression more attractive, Chief Justice Dickson disagreed:

Governmental disapproval of hate propaganda does not invariably result in dignifying the suppressed ideology. Pornography is not dignified by its suppression, nor are defamatory statements against individuals seen as meritorious because the common law lends its support to their prohibition ... In this context, no dignity will unwittingly be foisted upon the convicted hate-monger or his or her philosophy...57

Supra note 3 at 755.

lbid. at 758.

Ibid. at 759 .

Ibid. at 762 .

Ibid. at 767.

Ibid. at 769 .

Ibid. 
Finally, as to the argument that the Weimar Republic ${ }^{58}$ had laws similar to s. 319(2) "and yet these laws did nothing to stop the triumph of a racist philosophy under the Nazis," ${ }^{\prime 9}$ Chief Justice Dickson responded that no claim had been made that s. 319(2) could by itself prevent a tragedy like the Holocaust. That is not, however, a compelling reason for the repeal or removal of such laws from the Canadian Criminal Code.

In the Zundel case, the Court concluded that s. 181 of the Code did not constitute a minimal impairment of freedom of expression. In particular, the phrase "public interest" caused a serious problem of "overbreadth".

With respect to this branch of the Oakes test, s. 319(2) was also challenged as being overbroad and unjustifiably vague, thus creating "a real possibility of punishing expression that is not hate propaganda." ${ }^{60}$ In order to dispose of this contention, Chief Justice Dickson focused on the terms of s. 319(2), the defences to the charge (in s. 319(3)), and the alternative methods available to fulfil Parliament's objective.

a. Terms of section 319(2):

Chief Justice Dickson first noted that s. 319(2) specifically exempts private conversation from its scope. He stated that this was an indication that Parliament was not encroaching on the privacy of individuals through the use of the section.

The Chief Justice then examined the word "wilful". The presence of this word had been previously held to indicate that the mens rea requirement of s. 319(2) is that of intention to promote hatred, or the knowledge that promotion of hatred is foreseeable or substantially certain to result from an act done in pursuit of another purpose. ${ }^{61}$ The majority held that this "stringent" mental element requirement severely limited the reach of s. 319(2):

[T] his stringent standard of mens rea is an invaluable means of limiting the incursion of s. 319(2) into the realm of acceptable (though perhaps offensive and controversial) expression. It is clear that the word "wilfully" imports a difficalt burden for the Crown to meet and, in so doing, serves to minimize the impairment of freedom of expression. ${ }^{62}$

The Alberta Court of Appeal (in the decision that formed the subject of the appeal to the Supreme Court) had held that "even a demanding mens rea component fails to give s. 319(2) a constitutionally acceptable breadth," ${ }^{63}$ largely because of the fact that the

For a discussion of the laws of the Weimar Republic, see C. Levitt, "Racist Incitement and The Law: The Case of the Weimar Republic" in D. Schneiderman, Freedom of Expression and the Charter (Toronto: Carswell, 1991) and C. Levitt "Under the Shadow of Weimar: What are the Lessons for the Modern Democracies?" in L. Greenspan \& C. Levitt, eds., Under the Shadow of Weimar: Democracy, Law and Racial Incitement in Six Countries (Westport, CT: Praeger, 1993).

Ibid. at 771 .

R. v. Buzzanga (1979), 25 O.R. (2d) 705 (Ont. C.A.).

Supra note 3 at 775.

Ibid. at 775-76. 
section does not require proof of actual hatred resulting from a communication. Chief Justice Dickson held that to require proof of actual hatred "gives insufficient attention to the severe psychological trauma suffered by members of those identifiable groups targeted by hate propaganda." ${ }^{64} \mathrm{He}$ further stated that such a requirement would seriously weaken the section's effectiveness because a causative link between a specific statement and resulting hatred would be extremely difficult to prove.

The third aspect of s. 319(2) dealt with by Chief Justice Dickson was the phrase "promotes hatred against any identifiable group;" in particular, the words "promotes" and "hatred" were examined. The Chief Justice found "promotes" to mean "active support or instigation," ${ }^{65}$ or "more than simple encouragement or advancement." 66 With respect to the word "hatred", his lordship stated that it must be interpreted "according to the context in which it is found," and that in the context of s. 319(2), the term "connotes emotion of an intense and extreme nature that is clearly associated with vilification and detestation."67 In this sense, "hatred" is restricted to cover only the most "intense form of dislike." ${ }^{168}$

\section{b. Defences to section 319(2)}

The specific statutory defences provided in s. 319(3) were held to further limit the scope of the provision in that they were:

intended to aid in making the scope of the wilful promotion of hatred more explicit ... To the extent that s. 319(3) provides justification for the accused who would otherwise fall within the parameters of the offence of wilfully promoting hatred, it reflects a commitment to the idea that an individual's freedom of expression will not be curtailed in borderline cases. ${ }^{69}$

It was argued that the defence of truth (s. 319(3)(a)) was inadequate protection against an overly broad hate propaganda law. It would often be difficult to classify statements as being "true" or "false". This would result in a "chilling effect" on speech as persons who feared prosecution would exercise self-censorship. Chief Justice Dickson, however, rejected this argument.

\section{c. Alternative Modes of Furthering Parliament's Objective}

It was argued before the Court that criminal sanction was not necessary to meet the legislative objective in enacting s. 319(2); that in fact other methods would be more effective in combatting the harm resulting from hate propaganda. Among suggested alternatives were information, education and human rights legislation. The Court held that it is open to the government to employ several measures in order to fulfil its 
objective, and that "s. 1 should not operate in every instance so as to force the government to rely upon only the mode of intervention least intrusive of a Charter right ...." ${ }^{770}$ In result, the Court held that section 319(2) did not "unduly impair the freedom of expression." $" 1$

Justice McLachlin, in the Zundel decision, held that weighing the effects of the legislation against its objective led to the finding that the effects of s. 181 were not proportional to its objective. She stated:

Any purpose which can validly be attached to $\mathrm{s}$. 181 falls far short of the documented and important objective of s. 319(2). On the other side of the scale, the range of expression caught by s. 181 is much broader than the more specific proscription of s. 319(2). ${ }^{72}$

In summarizing the s. 1 analysis, Justice McLachlin stated that "at virtually every step of the Oakes test, one is struck with the substantial differences between s. 181 and the provision at issue in Keegstra." ${ }^{173}$ She held that $\mathrm{s} .181$ could not be related to any "existing social problem or legislative objective," and that the provision was, as concluded by the Law Reform Commission, "anachronistic".

In the Keegstra decision, Chief Justice Dickson held that because of the limited value of the expression prohibited by s. 319(2), and because of the great importance of the legislative objective underlying the section, the effects of the provision on freedom of expression did not outweigh Parliament's objective.

\section{A. CONCLUSION}

Although, it may be argued that the Zundel decision was the product of a changed composition of the Court since the judgment in Keegstra, ${ }^{74}$ Justice McLachlin's use of the Keegstra decision (a decision in which she dissented) as a benchmark for evaluation of the false news provision, nonetheless, confirms the constitutionality of the hate propaganda provision and the validity of the analysis employed in Keegstra itself.

Furthermore, it is clear that the different results in these two cases turned, in large measure, on the originally articulated objective underlying each provision. In Zundel, the original objective behind s. 181 - to ensure political harmony in the realm - had no currency and, thus, was not pressing and substantial. The concept of "shifting purpose" was rejected by the majority. The original purpose behind the hate propaganda provisions still has relevance today (perhaps even more so than when it was legislatively adopted). Consequently, the purpose was seen as pressing and substantial.

Ibid. at 784.

Ibid. at 786.

Supra note 23 at $775-776$.

Ibid. at 776.

The issue of the changed composition of the Court and its potential effect on the Zundel decision was discussed in B. Elman, "Supreme Court Upholds Hate Propaganda Law" (1991) 2 Const. Forum 86-89. See also B. Elman, "Her Majesty the Queen v. James Keegstra: The Control of Racism in Canada" in Greenspan \& Levitt, eds., supra note 58. 
Thus, recent legislation has a better chance of passing muster than does older legislation (recall that s. 181 was described as "anachronistic"). This will remain so as long as the concept of "shifting purpose" is rejected by the courts. Undoubtedly, this issue will be revisited in future cases.

The other salient observation arising from a comparison of the judgments is that $\mathbf{s}$. 319(2) was upheld because of the narrow drafting of the section and the creation of special statutory defences in s. 319(3). Thus the text of s. 319(2), itself, is its most valuable feature from a constitutional perspective, but also makes it quite difficult to employ from the perspective of the enforcement of the criminal law. Maybe this is the answer: it is difficult to secure a conviction on s. 319(2) and so it should be.

Yet, the question remains: can s. 319(2) be used to successfully prosecute Holocaust deniers like Zundel? The issue of Holocaust denial did not play a major role in the Keegstra case, even though it was present. Although there is a strong argument to be made that those who deny the Holocaust (and publish books and pamphlets to that end) are wilfully promoting hatred against Jews, no precedents exist wherein the courts have accepted Holocaust denial propaganda as statements promoting hatred. Nonetheless, it is sobering to recall that the Zundel prosecution was initially commenced under s. 181 by the Holocaust Remembrance Association because the Attorney General of Ontario refused to prosecute him under s. 319(2), fearing that a conviction could not be secured.

Finally, there is important symbolic value in having a law prohibiting the dissemination of hate propaganda. Our society must make a clear statement as to the values which we deem of central importance. If we believe that equality, the protection of minorities, and the preservation of multiculturalism are important to Canadian society, we must be prepared to support these values with criminal sanctions if necessary. Indeed, although no causal connection likely exists, there was an alarming increase in overt acts of racism and anti-semitism in Alberta following the Alberta Court of Appeal's decision to strike down the hate propaganda law in 1988 (witness the pins protesting the use of turbans by Sikh members of the RCMP, the skinhead attack on former broadcaster Keith Rutherford for having exposed a Nazi war criminal a number of years earlier, and the cross-burning at Provost, Alberta accompanied by chants of "Death to the Jews").

Nonetheless, the criminal process is long, expensive, and, most importantly, unpredictable. It should not be casually invoked. Alternative legal means - perhaps human rights legislation - should be studied to determine if they might be effective in combatting racism. The case of Malcolm Ross and other human rights decisions may point to new ways of deterring racist incitement, and it is to these cases that we now direct our attention. ${ }^{75}$ It may transpire, however, that minority religious and ethnic groups will be forced to develop extra-judicial strategies to combat racist incitement or remain at the mercy of the hate monger. 


\section{ALTERNATIVES TO CRIMINAL SANCTIONS: ROSS, TAYLOR AND THE ARYAN NATIONS}

There are other methods of dealing with hate propaganda which, it is argued, are more efficient and appropriate than the imposition of criminal sanctions. Alternatives to sanctions under the Criminal Code include education and social policy, as well as human rights legislation.

Education in theory should be an effective method of combatting the dissemination of hate against identifiable groups. If the public were informed of the truth, there would be nothing to fear from hate-mongers. They would simply be dismissed as not being credible. However, education alone cannot be the sole solution to the problem of racist incitement. It would be extremely difficult, if not impossible, to create and monitor an educational program on a province or nation-wide scale. The Keegstra case should provide sufficient evidence to show that serious problems in an educational system can go unnoticed for long periods of time.

As for social policy, it can be a useful adjunct, but again, it is not a solution in itself. Government endorsement of a particular policy can be valuable in that society will, hopefully, conform to the spirit of the policy. A policy is merely a statement of desire and the problem arises when individuals do not adhere to the policy because there is no mechanism for enforcement. Further discussion of education and social policy alternatives is not within the scope of this paper, and we will now turn our attention to human rights legislation.

Human rights have been described as "those fundamental rights to which every man or woman ... is entitled merely by virtue of having been born a human being. ${ }^{176}$ In contrast to the purposes of punishment and deterrence of the criminal law, the purpose of human rights legislation has been described as the promotion of equal opportunity unhindered by racial discrimination. In order to effect this goal, Canadian statutes normally create a human rights commission which investigates complaints and, if a complaint is found to have merit, attempts to reach a settlement between the parties. If no settlement can be reached, the commission has the ability to appoint a board of inquiry to determine how the situation can best be resolved. In contrast to the adversarial aspects of the criminal law, the resolution of problems by way of human rights legislation involves conciliation and negotiation.

In general, human rights legislation deals with the prevention of discrimination in relation to employment, accommodation, and provision of services available to the public. Section 5 of the New Brunswick Human Rights Code ${ }^{77}$ was invoked in the case of Attis v. New Brunswick School District No. 15 (the Malcolm Ross case). ${ }^{78}$ Section 5 provides: 
No person, directly or indirectly, alone or with another, by himself or by the interposition of another, shall

(a) deny to any person or class of persons the accommodation, services or facilities available to the public, or

(b) discriminate against any person or class of persons with respect to any accommodation, services or facilities available to the public,

because of race, colour, religion, national origin, ancestry, place of origin, age, marital status or sex.

\section{A. MALCOLM ROSS}

In 1991, a complaint was advanced to the New Brunswick Human Rights Commission by Moncton resident David Attis against Malcolm Ross, a teacher employed by the Moncton School Board, as well as against the School Board itself. The allegations made by Mr. Attis were that Ross had created a "poisoned atmosphere" in the school district by making anti-Semitic comments in the form of publications, a television interview and a letter to a local newspaper. He further alleged that the School Board "by its own statements and inaction over Malcolm Ross' statements in class and in public [had] condoned his views." ${ }^{79}$ Because a settlement between the parties could not be reached, a Board of Inquiry was set up to look into the allegations and resolve the matter. The Board of Inquiry had to determine whether there was merit to the complaints and whether a prima facie case of discrimination had been made out, both against Ross and the School Board. First, however, the Board of Inquiry was required to decide whether section 5 of the Code could apply to educational services. The Board held that the section:

guarantees individuals freedom from discrimination in educational services available to the public.... [e]ducation of students must be viewed in the broad context of including not only the formal curriculum but the more informal aspects of education that come through interchange and participation in the whole school environment. ${ }^{80}$

The remedy proposed by the Board included some recommendations for action by the Department of Education and the School Board. The recommendations made by the Board of Inquiry were as follows:

(1) That the Department of Education:

(a) establish an annual review process to set goals and to assess progress on the implementation of the initiatives set out in the Ministerial Statement on "Multicultural/Human Rights Education";

(b) develop in collaboration with school trustees and teachers a system of periodic appraisals of the overall quality of race relations in the school environment and procedures for responding to any discriminatory situations identified; 
(c) encourage all school boards to implement a policy which will clearly establish the commitment of each board and teachers within that board to teach respect for individual rights and tolerance of differences; and

(d) review the Schools Act in consultation with the New Brunswick Teacher's Association to determine whether it would be appropriate to define within it a clear statement as to the level of professional conduct expected of teachers in the Province of New Brunswick.

(2) That the School Board:

(a) immediately place Malcolm Ross on a leave of absence without pay for a period of eighteen months;

(b) appoint Malcolm Ross to a non-teaching position if, within the period of time that Malcolm Ross is on leave of absence without pay, a non-teaching position becomes available in School District 15 for which Malcolm Ross is qualified. The position shall be offered to him on terms and at a salary consistent with the position. At such time as Malcolm Ross accepts employment in a non-teaching position, his leave of absence without pay shall end.

(c) terminate Malcolm Ross' employment at the end of the eighteen month leave of absence without pay if, in the interim, he has not been offered and accepted a non-teaching position.

(d) terminate Malcolm Ross' employment with the School Board immediately if, at any time during the eighteen month leave of absence or if at any time during his employment in a nonteaching position, he:

(i) publishes or writes for the purpose of publication, anything that mentions a Jewish or Zionist conspiracy, or attacks followers of the Jewish religion, or (ii) publishes, sells or distributes any of the following publications, directly or indirectly: Web of Deceit, The Real Holocaust (The Attack on Unborn Children and Life Itself). Spectre of Power, Christianity vs. Judeo-Christianity (The Battle for Truth). ${ }^{81}$

The order was appealed to the New Brunswick Court of Queen's Bench. ${ }^{82}$ The recommendations made with respect to the Department of Education were quashed. The Court held that the Board did not have jurisdiction to make an order for compliance simply because the Department was named as a party to the action. There had been no investigation of, or claim or finding against, the Department. As well, the final clause of the order respecting the School Board ("terminate Malcolm Ross' employment with the School Board immediately if, at any time during the eighteen month leave of absence or if at any time during his employment in a non-teaching position...") was set aside, since it required the Board to terminate Ross' employment (even if he was not employed as a teacher at the relevant time) in the event of further publication of anti- 
Semitic literature, and this was held to be impermissible. The only time that the Board's orders could be legitimately exercised against Ross was when he was employed in the classroom. In result, however, the order made by the Board was upheld upon judicial review by the New Brunswick Court of Queen's Bench. The Board's order was challenged on the basis that it violated section 2(b) of the Charter, but the Court held that while section 2(b) was violated, the infringement of the Charter right was "reasonable and demonstrably justified in a free and democratic society."

Malcolm Ross appealed this decision, and the appeal was heard in August 1992. The decision of the New Brunswick Court of Appeal was delivered on December 20, $1993^{83}$

Ross was successful in having the order of the Board of Inquiry quashed in the Court of Appeal. Chief Justice Hoyt delivered the reasons of the majority, with Justice Angers concurring. The Court of Appeal held, as had the Court of Queen's Bench, that the order violated Ross' right to freedom of expression. The Court of Appeal then went on to find that the order could not be justified as a reasonable limit under section 1 of the Charter.

In undertaking the section 1 analysis, Chief Justice Hoyt referred to the decision of the Supreme Court of Canada in the Zundel case. He relied on the decision as authority for the proposition that justification of a Charter right infringement requires the presence of a purpose that is sufficiently pressing and substantial. He stated:

the purpose of the order being reviewed here, namely Mr. Ross' removal from the classroom must be 'so pressing and substantial' before the constitutional guarantee of freedom of expression can be overridden by section $1 . . .{ }^{84}$

The Chief Justice held that Ross had not attempted to propound his antisemitic views in the classroom, and no connection could be drawn between Ross' statements and the "offensive remarks" ${ }^{15}$ that formed part of the subject matter of the complaint. Therefore, according to his Lordship, there was not sufficient evidence upon which to ground such a severe restriction on Ross' freedom of expression as was accomplished by the Board's order.

The majority opinion does recognize the fact that, as a teacher, Ross was a role model and had a "unique opportunity to influence youthful minds. ${ }^{186}$ However, as there was no evidence that Ross used his classroom or other school property to disseminate his views, the majority was unable to find that the restriction of a Charter right was justifiable.

Ibid. at 14 of majority reasons. 
The Chief Justice stated:

In such circumstances, I do not conclude that this remedy, which violated Mr. Ross' constitutional guarantee of freedom of expression, meets the requirement of being "a specific purpose so pressing and substantial" that the guarantee should be overridden. To hold otherwise would, in my view, have the effect of condoning the suppression of views that are not politically popular at any given time. ${ }^{87}$

The decision of the majority presents several problems. First, Chief Justice Hoyt seems to be saying that the purpose of the remedy (i.e. the Board order) is to remove Ross from the classroom, and that this purpose is not so pressing and substantial as to warrant overriding a Charter right. This does not seem to be an accurate view of the "purpose" at issue in this case. The dissent, written by Justice Ryan, characterizes the objective in question in this case as the prohibition of discrimination; in other words, the purpose underlying the Human Rights Act. This is a more appropriate characterization of the purpose behind the order of the Board of Inquiry. The order itself is the means of effecting the purpose of the legislation - the suppression of discrimination - and should be examined within the "rational connection" branch of the proportionality test under section 1, rather than as part of the "purpose or objective" test. This is the analysis employed by Justice Ryan in dissent.

A second difficulty that emerges from the reasons of the majority is that it disregards and minimizes the impact of the statements and actions of a teacher outside of the classroom. That Ross is a role model for children is a fact which exists regardless of whether he speaks inside or outside of the classroom. As Justice Ryan states:

We cannot in this age of pervasive mass communication, repetitious radio and television news and public affairs programs, underestimate the cumulative effect on young people of statements made outside the classroom. They hear or see the news before and after school. To draw the line at the classroom door is an unrealistic barrier in this burgeoning age of information and communication. ${ }^{88}$

While Justice Ryan makes this assertion specifically in support of the reinstatement of clause 2(d) of the Board order (the part that was quashed on review in the Court of Queen's Bench), the statement applies equally to the entire order. The majority fails to recognize and give effect to the purpose of the Human Rights Act by requiring evidence that Ross attempted to further his views in the classroom or, absent that, evidence of a direct link between his out of school statements and anti-semitic remarks made to Jewish students by other students.

Another problem with the majority decision surfaces in the statement made by Chief Justice Hoyt that if the court were to uphold the Board order, the decision would "have the effect of condoning the suppression of views that are not politically popular at any given time." ${ }^{89}$ This assertion implies first, that all expression is worthy of the same degree of protection under the Charter regardless of its content, and second, that the

Ibid. at 11 of dissent.

Ibid. at 14 of majority reasons. 
only reason that Malcolm Ross' anti-semitic ideas and opinions are disturbing to Canadian society is that they are not politically popular at present. Ross' anti-semitic views are not simply politically unpopular, they are false and malicious, and directed at harming a specific identifiable religious group. As then Chief Justice Dickson stated in Keegstra, expression such as this, while deserving of protection within the scope of section 2(b) of the Charter, is only tenuously connected to the core values underlying freedom of expression and consequently lies at the periphery of the section's scope. This suggests that prohibitions on this type of expression can be more easily justified under section 1 of the Charter than might other limitations on speech which is more central to the values upon which the freedom is based. ${ }^{90}$

Finally, the main flaw in the New Brunswick Court of Appeal decision is that the Court fails to appreciate the fundamental importance of human rights legislation. It has been recognized by the Supreme Court of Canada that human rights statutes are to be given a "large and liberal" interpretation. ${ }^{91}$ The decision of the Court of Appeal does not adhere to this principle of interpretation; in fact, the majority reasons are based on a very narrow, literal and technical approach to statutory interpretation.

The dissenting judgment in this case, as suggested earlier, provides a more compelling characterization of the issues and of the purpose of the legislation pursuant to which the order was made. Justice Ryan maintained that freedom of expression is not absolute. As with all important values, it must be balanced against competing interests; in this case, that of prohibiting discrimination. He held that the entire Board order was justifiable under section 1 of the Charter and should stand, including clause 2(d) which had been previously overturned by Justice Creaghan in the Court of Queen's Bench. According to Justice Ryan:

\begin{abstract}
A balance must be struck between Ross' freedoms, the victims' freedoms and an educational system which teaches impartiality and does not espouse prejudice, bigotry or bias. A teacher teaches. He is a role model. He also teaches by example. Children learn by example. Malcolm Ross teaches by example. He is a role model who publishes and promotes prejudice. ${ }^{92}$
\end{abstract}

\title{
B. JOHN ROSS TAYLOR
}

Some sections of the various human rights codes, such as section 13(1) of the Canadian Human Rights Act, ${ }^{93}$ attempt to deal more specifically with racist expression. Section 13(1) provides:

It is a discriminatory practice for a person or a group of persons acting in concert to communicate telephonically or to cause to be so communicated, repeatedly, in whole or in part by means of the facilities of a telecommunication undertaking within the legislative authority of Parliament, any matter 
that is likely to expose a person to hatred or contempt by reason of the fact that that person or those persons are identifiable on the basis of a prohibited ground of discrimination.

According to section 3(1) of the Act, prohibited grounds of discrimination are "race, national or ethnic origin, colour, religion, age, sex, marital status, family status, disability, and conviction for which a pardon has been granted." 94

Section 13(1) was considered in Nealy v. Johnston. ${ }^{95}$ This case involved complaints made regarding the telephone messages communicated by Randy Johnston, Terry Long, and the Church of Jesus Christ Christian Aryan Nations. One message stated, in part:

our first case in point is the 155 Tamils who purposely lied their way onto Canadian soil ... 20,000 Tamils who now reside in West Germany have been flown in by East German Aeroflot planes since 1983 ... Many other third world immigrants who came in from Europe are heavily involved in the world drug trade.

Another message included:

We in the Aryan Nations know that this Satanic religion [Judaism] is a conspiracy against our Lord Saviour Jesus Christ and clearly promotes hatred against his followers. If you are still in doubt, let me pass on one more quote from the Talmud. Those who kill Christians shall have a high place in heaven. How touching!

The Human Rights Tribunal found that the messages were likely to expose a person or persons to hatred or contempt by reason of the fact that they are part of an identifiable group. In particular, the messages focused on immigrants from Third World countries (mainly Sikh, Tamil and Vietnamese individuals), and on Jewish people.

Section 13(1) was challenged as an infringement of section 2(b) of the Charter, but the Tribunal found that the infringement was justified under section 1. The Tribunal applied the Oakes test, and determined that section 13(1) was justifiable under section 1 of the Charter - it was rationally connected to the legislative objective, it was a minimal impairment of freedom of expression and its effects did not outweigh its purpose. The Human Rights Tribunal ordered Long, Johnston, and the Church of Jesus Christ-Christian Aryan Nations to cease communicating discriminatory messages over the telephone, and to refrain from such activity in the future. ${ }^{96}$

The Supreme Court of Canada recently upheld the constitutional validity of the same section of the Canadian Human Rights Act. The Supreme Court used much the same reasoning as had the tribunal in Nealy v. Johnston. The Taylor ${ }^{97}$ case commenced in 1979, when the Human Rights Tribunal ordered John Ross Taylor and the Western

Ibid. s. 3(1).

(1989), 10 C.H.R.R. D/6450.

Supra note 79 at $\mathrm{D} / 6487$.

Canada (Canadian Human Rights Commission) v. Taylor (1990), 75 D.L.R. (4th) 577 (S.C.C.) [hereinafter Taylor]. 
Guard Party to "cease and desist" their telephonic communication of "hate messages". Since mid-1977, Taylor had been producing hate messages and communicating them by telephone. One of Taylor's messages stated the following:

Without freedom of speech we'd perish. Few know what communism really is...to truly expose communism is the great no no. But moral decay, economic problems and war are all coming from the same source that produces communism.... The Fed's Kuhn-Loeb High Bank financed the Russian Revolution. December Thunderbolt, which is banned in Canada, states Andropov's real name is Lieberman.... Toronto Star, November 14, states of Andropov: "His mother's family is almost certainly Jewish". The founder of communism, Karl Marx, whose real name was Moses Mordecai Levy, was the grandson of Rabbi Mordecai. The founder of the Soviet Army was Trotsky, whose real name is Bronstein. Help the Western Guard expose these bankers and their agents. Send funds and mail to...

After the order was issued by the Tribunal, it was filed with the Federal Court, Trial Division, thus becoming an order of the Court. When Taylor and the Western Guard Party did not cease their discriminatory practice, the Human Rights Commission applied to the Federal Court to enforce the order. The Court sentenced the Western Guard Party to pay a $\$ 5,000$ fine and sentenced Taylor to one year in prison. The contempt order was suspended on condition that the discriminatory practice be stopped. When the cease and desist order was still not complied with, the suspension of the contempt order was vacated. The Party paid its fine and Taylor served his sentence, with remission, between October 17, 1981 and March 19, 1982. Upon his release, Taylor recommenced his telephone message service and was again before the Court at the request of the Commission. Taylor attempted to challenge the constitutional validity of section 13(1) of the CHRA as he alleged it infringed his freedom of expression. The Federal Court decided that the section did violate section 2(b) of the Charter, but upheld it as a reasonable limit under section $1 . .^{98}$ The purpose of the CHRA was held to be pressing and substantial, and was found to minimally impair freedom of expression. An important factor in the Court's decision was that punishment does not occur unless the transgressor is "recalcitrant". The decision was appealed to the Federal Court of Appeal, and the finding of the Trial Division was upheld. ${ }^{99}$ The ruling of the Court of Appeal was appealed to the Supreme Court of Canada.

The Supreme Court released the Taylor decision at the same time as it released its reasons in Keegstra ${ }^{100}$ and Andrews and Smith. ${ }^{101}$ The majority of the Court held that section 13(1) of the Human Rights Act was a violation of the guarantee of freedom of expression, but constituted a reasonable limit in a free and democratic society. More specifically, in terms of the section 1 justification test, the Court first stated the objective of the $\mathrm{Act}$ as the promotion of equal opportunity unhindered by discriminatory practices. In support of this pressing and substantial objective, the Court cited sections 15 (equal protection) and 27 (multicultural heritage) of the Charter.

Taylor v. Canada (Canadian Human Rights Commission) (1984), 6 C.H.R.R. D/2595 (Fed. Ct. T.D.).

Taylor v. Canada (Canadian Human Rights Commission), [1987] 3 F.C. 593 (C.A.).

Supra note 3.

Supra note 14. 
In undertaking the proportionality test, the Court found that section 13(1) was rationally connected to Parliament's objective. According to Chief Justice Dickson (writing for the majority),

Once it is accepted that hate propaganda produces effects deleterious to the guiding principles of section 2 of the Canadian Human Rights Act, there remains no question that section 13(1) is rationally connected to the aim of restricting activities antithetical to the promotion of equality and tolerance in society. ${ }^{102}$

Chief Justice Dickson further stated that the nature of the human rights procedure as "conciliatory" and the absence of criminal punishment makes the section particularly well-suited to Parliament's aim.

With respect to the minimal impairment branch of the proportionality analysis, the Court held that while human rights statutes must be given a "large and liberal" interpretation, the section here at issue was not overbroad. The Court argued that as long as the purpose of protecting "the equality and dignity of all individuals by reducing the incidence of harm-causing expression"103 was kept in mind by the Tribunal when interpreting the Act, the issue of overbreadth would not be of concern. Further, the Court held that while section 13(1) of the CHRA imposed a broader limitation on freedom of expression than did section 319(2) of the Criminal Code, "the conciliatory bent of a human rights statute renders such a limit more acceptable than would be the case with a criminal prohibition." 104

As to the argument that the section was overbroad because of its lack of an "intent" requirement, the Court responded that the concern of human rights legislation is with the effects of discriminatory practices, not the intent of the person involved in the practice. According to the Court, "systemic discrimination is much more widespread in our society than is intentional discrimination. ${ }^{\text {"105 }}$ Chief Justice Dickson stated that the lack of an intent requirement did not cause the statute to overshoot its mark because the only way that the legislative objective underlying the section could be met was by "ignoring" intent. He further held that any chilling effect on speech which might arise because of the absence of an intent requirement would be less with a human rights statute than with a criminal provision.

The appellant argued further that the section was overbroad because there was the possibility of imprisonment for breach of the statute without even a requirement that the discrimination be intentional. The Court held that a transgressor cannot be imprisoned unless the order of the Tribunal is contravened, and that once such an order has been filed with the court, the transgressor can no longer claim to be "innocent or 
negligent as to the effects of his or her message, and hence the spectre of imprisonment absent intent is dispelled." 106

The effects of section 13(1) were held to be proportional to the objective of Parliament in enacting the section. The Court stated that:

operating in the context of the procedural and remedial provisions of the Canadian Human Rights Act, section 13(1) plays a minimal role in the imposition of moral, financial or incarceratory sanctions, the primary goal being to act directly for the benefit of those likely to be exposed to the harms caused by hate propaganda. ${ }^{107}$

The dissent held that section 13(1) was overbroad, and that this problem with the section could not be overcome by the "sensitive and appropriate enforcement procedure established by the Act." ${ }^{108}$

\section{THE ARYAN NATIONS}

A third type of provision commonly found in human rights legislation is one which prohibits discrimination by publication or display of a "notice, sign, symbol, emblem or other representation." The Saskatchewan provision ${ }^{109}$ was interpreted in Saskatchewan (Human Rights Commission) v. Bell. ${ }^{110}$ Bell had allegedly contravened the Saskatchewan Human Rights Code by selling stickers in his retail store that portrayed stereotypical images of black, oriental and East Indian persons in a red circle with a red line through the circle. An expert witness that came before the Board of Inquiry stated that the stickers reflected racist attitudes toward minority groups. The Saskatchewan Code was challenged as being a violation of section 2(b) of the Charter because of allegedly vague words such as "affront the dignity." The Queen's Bench justice stated that although section 14(1) of the Code was a violation of freedom of expression, it could nonetheless be saved by section 1 of the Charter. Section 14(1) provided:

No person shall publish or display, or cause or permit to be published or displayed, on any lands or premises, or in a newspaper, through a television or radio broadcasting station or any other broadcasting device or in any printed matter or publication or by means of any other medium that he owns, controls, distributes or sells, any notice, sign, symbol, emblem or other representation tending or likely to tend to deprive, abridge or otherwise restrict the enjoyment by any person or class of persons of any right to which he is or they are entitled under the law, or which exposes, or tends to expose, to hatred, ridicules, belittles, or otherwise affronts the dignity of, any person or class of persons

Ibid.

Ibid. at 609.

Ibid. at 624.

Saskatchewan Human Rights Code, S.S. 1979, c. S-24.1 as am.

(1991), 88 D.L.R. (4th) 71 (Sask. Q.B.). 
or a group of persons because of his or their race, creed, religion, colour, sex, marital status, physical disability, age, nationality, ancestry or place of origin. ${ }^{11}$

The objective of the legislation was held to be "the prevention of harms caused by messages which undermine the dignity and self-worth of target group members...," 112 and this objective was pressing and substantial enough to warrant overriding a Charter right. The proportionality test was also met, provided that the words of the statute were interpreted "in view of the objects of the ... Code."113 An order was made for a permanent injunction to restrain the defendant from selling or displaying the sticker which depicted the caricature of the East Indian individual. Two other complainants were held by the judge not to have standing and were dismissed.

Warren v. Chapman ${ }^{114}$ concerned an inquiry under the Manitoba Human Rights Code ${ }^{115}$ involving two newspaper articles written by the applicant that "indicated discrimination or intention to discriminate against native peoples."116 The applicant (Warren) applied to the court for an order prohibiting the Board of Adjudication from entering into an inquiry under the Act. The basis of the application was that section 2(1) of the $A c t$ did not apply to a newspaper article or editorial. The section provided:

No person shall

(a) publish, display, transmit, broadcast, or cause to be published, displayed, transmitted or broadcast; or

(b) permit to be published, displayed, transmitted or broadcast to the public, on lands or premises, in a newspaper, through television or radio or telephone, or by means of any other medium which he owns or controls:

any notice, sign, symbol, emblem or other representation

(c) indicating discrimination or intention to discriminate against a person; or

(d) exposing or tending to expose a person to hatred

Section 14(1) was amended in 1989; it now reads:

No person shall publish or display, or cause or permit to be published or displayed, on any lands or premises, or in a newspaper, through a television or radio broadcasting station or any other broadcasting device or in any printed matter or publication or by means of any other medium that he owns, controls, distributes or sells, any representation, including without restricting the generality of the foregoing, any notice, sign, symbol, emblem, article, statement or other representation;

(a) tending or likely to tend to deprive, abridge or otherwise restrict the enjoyment by any person or class of persons of any right to which he is or they are entitled under law; or

(b) which exposes or tends to expose, to hatred, ridicules, belittles, or otherwise affront the dignity of any person, any class of persons or a group of persons;

because of his or their race, creed, religion, colour, sex, marital status, disability, age, nationality, ancestry or place of origin.

\section{Supra note 110 at 92.}

Ibid. at 94.

(1984), 11 D.L.R. (4th) 474 (Man. Q.B.).

C.C.S.M., c. H-175 as am., enacted by S.M. 1987-88, c. 45.

Supra note 114 at 474. 
because of the race, nationality, religion, colour, sex, marital status, physical or mental handicap, source of income, family status, ethnic or national origin of that person. ${ }^{117}$

The Court agreed with the applicant that "other representation" did not extend to include newspaper articles. Representation was held to mean "image or likeness", and the court stated that if the legislature had intended to include more complex works such as newspaper articles or editorials, they would have done so expressly. According to the Justice:

Giving the ordinary and natural meaning to the words in question, it cannot, in my view, be said that they include in their meaning relatively complex literary works such as newspaper articles or editorials. ${ }^{118}$

The application was therefore granted and the inquiry did not proceed. On appeal to the Manitoba Court of Appeal, ${ }^{119}$ the order of the Queen's Bench justice was upheld and the appeal dismissed. The Court of Appeal could not find evidence of intention of the legislature to include newspaper articles or editorials within the scope of the section. This precedent could have significant implications for any attempt to deal with hate propaganda under human rights legislation as much of the racist material which might be the subject of proceedings under section 319(2) of the Criminal Code are written materials which could be described as "complex literary works." If the terms "notice, sign, symbol or emblem" are always strictly interpreted in such a manner as to exclude editorials and articles, then much of the material which falls under the criminal law will not be subject to human rights enforcement and human rights legislation will fail as an alternative.

A similar precedent is found with respect to the Saskatchewan Human Rights Code. In Saskatchewan (Human Rights Commission) v. Engineering Students' Society ${ }^{120}$ the complaint concerned "The Red Eye", a student university newspaper. The newspaper in question contained material which was considered to be degrading to women. The Board held that the Code had been violated. However, on appeal to the Court of Queen's Bench, the Board's determination was overturned. The Queen's Bench justice held that the Board had erred in interpreting the Code to give all women in Saskatchewan the "right not to be discriminated against by means of hate literature and

The section has since been amended to read:

No person shall publish, broadcast, circulate or publicly display, or cause to be published, broadcast, , circulated or publicly displayed, any sign, symbol, notice or statement that

(a) discriminates or indicates an intention to discriminate in respect of an activity or undertaking to which this Code applies; or

(b) incites, advocates or counsels discrimination in respect of an activity or undertaking to which this Code applies; unless a bona fide and reasonable cause exists for this discrimination.

For further discussion see K. Mahoney, "The Human Rights Alternative to Racial Incitement" (Paper presented at a conference on Racial Incitement and the Law: Canada and Israel, Hebrew University, Mt. Scopus, Jerusalem) [unpublished]. 
group defamation."121 Section 14(1), as interpreted by the Board, was held to go beyond the jurisdiction of the province because it was, in pith and substance, criminal law. The Court stated that there are hate literature and group defamation provisions in the Criminal Code in order to control this issue. The Queen's Bench justice held that the Board's interpretation of the section was an error in law. Further, the Board failed to correctly ascertain that all of the objectionable material actually fell within the scope of the section and, in particular, the phrase "sign, symbol, emblem or other representation" and rather simply assumed that the material was all covered by section 14(1). The decision of the Court of Queen's Bench was appealed to the Saskatchewan Court of Appeal. ${ }^{122}$ While the Court of Appeal disagreed with the judge in terms of his interpretation of the nature and purpose of the Code and the vires of section 14(1), they upheld his decision regarding the scope of section 14(1) as not encompassing newspaper articles or the general content of a newspaper. The Court concurred with the Manitoba Court of Queen's Bench that the phrase "notice, sign, symbol, emblem or other representation" did not include complex literary works such as newspaper articles. On this point, the Court held that "( $t$ )he purpose of the Act pulls in one direction, the cast of the section in another." ${ }^{123}$ It is interesting to note that the Court also stated:

while we have concluded that the Board erred in law in having taken the impugned matter to fall within the scope of the section, we find ourselves in agreement with what the Board had to say, generally, about the offensive nature of the material and its destructive effects. ${ }^{124}$

This seems to be a comment on the unfortunate drafting of the human rights codes. Their purpose is admirable, and their remedies in terms of symbols or emblems which tend to promote discrimination can be effective in combatting intolerance and prejudice. However, much of the material that could be appropriately reviewed in the human rights realm can escape the grasp of the section. If material is "offensive" and has "destructive effects", and is found to be based on a prohibited ground of discrimination, then there is no logical reason why it should escape review under human rights statutes. Given the difficulty and expense of obtaining a conviction for this type of material in the criminal sphere, it seems to defy common sense to exclude it from human rights review. Clearly, the enacting bodies who drafted these statutes must have believed that there are reasons for excluding such material, but the statutes need to be re-examined and amended. Perhaps considerations such as these are what motivated the legislatures of Saskatchewan and Manitoba to amend their statutes to make them more comprehensive.

The British Columbia Human Rights Act ${ }^{125}$ was examined in the case of The Ukrainian Canadian Professional and Business Association of Vancouver v. William Konyk and the Winnipeg Garlic Sausage Co. Ltd. ${ }^{126}$ The Ukrainian Professional and

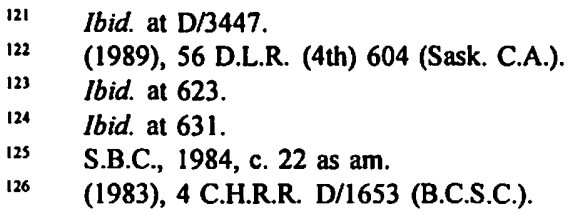


Business Association had made a complaint to the Human Rights Commission with respect to the name that the defendant was using for his restaurant, "Hunky Bill's". The Association argued that this was discriminatory in effect because it was offensive to other members of the Vancouver Ukrainian community. The Board ruled that there was no violation of the Code because the Code does not prohibit an individual from calling him or herself a name that would be offensive and discriminatory if they called someone else that name. In other words, the Board held that section 2(1) of the B.C. Code did not create a substantive offence; there must be evidence of discrimination in a manner prohibited by the $A c t$.

In Kane et al. v. Church of Jesus Christ-Christian Aryan Nations et al., ${ }^{127}$ a Board of Inquiry was created to look into complaints regarding a cross-burning ceremony in Provost, Alberta. The section of the Alberta Individual Rights Protection Act ${ }^{128}$ at issue was section 2, which provides:

2(1) No person shall publish or display before the public or cause to be published or displayed before the public any notice, sign, symbol, emblem or other representation indicating discrimination or an intention to discriminate against any person or class of persons for any purpose because of the race, religious beliefs, colour, sex, physical disability, age, ancestry or place of origin of that person or class of persons.

(2) Nothing in this subsection shall be deemed to interfere with free expression of opinion on any subject.

(3) Subsection (1) does not apply to

(a) the display of a notice, sign, symbol or other representation displayed to identify facilities customarily used by one sex,

(b) the display or publication by or on behalf of an organization that

(i) is composed exclusively or primarily of persons having the same political or religious beliefs, ancestry or place of origin, and

(ii) is not operated for private profit,

of a notice, sign, symbol emblem or other representation indicating a purpose of membership qualification of the organization,

(c) the display or publication of a form of application or an advertisement that may be used, circulated or published pursuant to section $8(2)$,

if the notice, sign, symbol, emblem or other representation is not derogatory, offensive or otherwise improper.

128 R.S.A. 1980 , c. $[-2$ as am. [hereinafter IRPA]. 
A sign and several symbols were involved in this "display" which was part of a socalled "Aryan Fest". In addition to the burning cross, there was a large Nazi battle flag hung on the side of a barn and many of the participants wore Nazi armbands which had swastika symbols on them. There was also a "KKK White Power" sign on the gate to the property where the Aryan Fest was held. The Board of Inquiry concluded that there was a violation of section 2(1) of the Individual Rights Protection Act and ordered that the Respondents refrain from the same or any similar display of discriminatory sign or symbols in the future. This was the "strongest order" the Board was permitted to make under the Individual Rights Protection Act.

Detailed reasons were given by the Board to explain their findings and to explain why the "strongest" order possible was necessary in this case. The Board first examined the nature and application of human rights legislation. Several cases were cited to demonstrate that human rights statutes are tantamount to a constitution in that they are to be accorded the status of a "fundamental law" and are to supersede all other laws in the event of conflict. The Board then discussed the issues arising from section 2 of the $I R P A$. Some of these issues will be examined here.

In determining whether the display of symbols "(indicated) discrimination," the Board considered two cases from other jurisdictions, ${ }^{129}$ as well as the dictionary definition of "indicate" and the case law definition of "discrimination". From these cases, the Board took three main points. First, the Board found that there did not have to be an actual act of discrimination in order to find "indication of discrimination." Only a "sign or symbol" of discrimination is required. Second, the Board found that displays which indicate discrimination can "endanger the rights of the target group to obtain equal opportunities in employment, housing and public accommodation." 130 Finally, the Board held that there need not be evidence of "intention to discriminate [in order] to find an indication of discrimination." ${ }^{131}$

The Board next examined the meaning of the sign and symbols used at the Aryan Fest in order to determine whether there was an intention to discriminate. Factors taken into account in making this determination were: the meaning of the sign and symbols to both the expert and non-expert witnesses, the meaning of the sign and symbols against the background of the National State Platform, and the meaning of the sign and symbols in the context of the Aryan Fest.

1. The Meaning of the Sign and Symbols to the Non-experts

The Swastika symbol reminded all of the witnesses of the Nazi regime under Hitler, and the "annihilation of Jews and opponents of the regime." 132 This symbol evoked 
images of persecution, and made the witnesses feel revulsion, as well as be "fearful for the Jews." ${ }^{133}$

The "KKK White Power" sign elicited thoughts of the Ku Klux Klan ("KKK"), and oppression of non-White Americans. One of the witnesses associated the sign with "White hooded men burning Black churches and hanging Blacks."134 The "burning cross" brought to mind similar images as the KKK sign. The symbols represented hatred and destruction of Blacks in the United States.

The Board found that the sign and symbols "communicated intense racial hatred and a threat of violence against Jewish and non-White persons." ${ }^{135}$ There was no difficulty in comprehending the message conveyed by these symbols; it was an invitation and encouragement to join in discriminating against Jewish and non-White people.

\section{The Meaning of the Sign and Symbols to the Experts}

The views of the expert witnesses coincided with those of the "non-experts" in terms of what the sign and symbols used at the Aryan Fest meant.

The first expert witness heard by the Board was Dr. Frances Henry, an anthropologist at York University. Dr. Henry was qualified as an expert witness "capable of expressing an opinion about racial discrimination, the history and meaning of symbols, and the anthropological effects of symbols in race relations." ${ }^{136}$ She testified that in North America today, the Swastika is almost invariably associated with the Nazi regime in Germany, even though in older civilizations (i.e. the Maya Indians, the Navajo Indians) the symbol meant good fortune. She further stated that the symbol "stands for the Nazi philosophy of destruction, annihilation, and eradication of nonAryan peoples...."137 Dr. Henry also stated that the words "White Power" and the letters "KKK" are symbols denoting White supremacy.

According to Dr. Henry, the symbols used at the Aryan Fest conveyed a number of different messages. The symbols played a propaganda function, communicating hatred of Jews and non-White persons, and a "commitment to their annihilation."138 She further testified that the symbols were used for recruitment of new members, as well as for "targeting and vilifying victims," 139 and for inspiring fear in victims. Finally, Dr. Henry stated that the symbols were employed to create a "climate of intolerance" against target groups. These symbols could, thus, act on existing racist or prejudicial tendencies of members of the public, and lead to discrimination.

$\begin{array}{ll}\text { I33 } & \text { Ibid. } \\ \text { 134 } & \text { Ibid. } \\ \text { 13s } & \text { Ibid. } \\ 136 & \text { Ibid. at } 51 . \\ 137 & \text { Ibid. at } 52 . \\ 138 & \text { Ibid. } \\ 139 & \text { Ibid. }\end{array}$


Dr. Ben Barkow was the next expert witness referred to by the Board. A psychologist from Toronto, he was qualified to give expert evidence on the effects of signs and symbols, and the public's reaction to and perception of signs and symbols. Dr. Barkow testified that the sign and symbols used at the Aryan Fest, as well as the activities that were taking place, could promote discrimination in several ways:

(1) "Imitative induction." Some people have a sense of similarity to those committing the violence. As they see the targets of violence, they choose a similar target. The more real the event, the more the imitation - and here, the event was totally real.

(2) "Priming." This is bringing events or activities or motivations to the focus of one's attention. When one sees on screen groups for which one may have a subtle feeling of dislike, and others taking part in some activity directed against these groups, this comes more to one's attention and one may dwell on this.

(3) "False sense of consensus." Media and others who observed the Aryan Fest found it difficult to estimate the number of people attending the rally. Others who become aware of the event may have a false sense of consensus, believing many people share bigoted views.

(4) "Contagion." This is the simple observation that after a dramatic act of violence, similar acts of violence take place.

(5) "Just World Concept." If a bigoted person sees a person of a certain race become a victim there is a tendency to believe the person deserved it, i.e. it must have been brought on by his own behaviour. Therefore, there is an increase in hatred for people who are victims or who are singled out as victims.

(6) "Weapons effect." Dr. Barkow said studies have shown that, not only when a weapon is in view, but for periods of days or weeks later, there is an enhancement of a sense of violence just from the visual contact with weapons. ${ }^{140}$

Ms. Johanna Buhr was the next expert heard by the Board; she was qualified as an expert in Canadian ethnic history. Her testimony dealt mainly with the history of the Ku Klux Klan in Alberta. She stated that the "racism and discrimination espoused by the "KKK" and others have contributed to a legacy of fear, suspicion and fragmentation in society." ${ }^{.141}$

Further expert testimony mainly affirmed the impressions given by the non-expert and other expert witnesses. 
3. The Meaning of the Sign and Symbols Against the Background of the National State Platform

The Board found that the meaning of the sign and symbols displayed at the Aryan Fest was affected by the "intentions or goals of the group making the display". In examining the connection between the Church of Jesus Christ Christian-Aryan Nations and the sign and symbols that they carefully chose, the Board found it necessary to discuss the National State Platform, which sets out the "goals and intentions" of the Church. According to the Board, the platform:

calls for the removal of non-Aryans from the territory of the new nation, and confiscation of their property and redistribution of their assets to the Aryans. Non-Aryans would not be able to vote or hold office in government, industry or society. They could not own property, conduct business or possess arms. They could not join the military or law enforcement agencies. Only Whites would be free of taxes above a ten percent tithe and would be eligible to receive interest-free loans. Only Whites would be free to perform mental or physical work they might choose.... ${ }^{142}$

The Board found that this platform violently contradicts the Individual Rights Protection Act and the values contained in it. The platform proposes widespread discrimination and the Board concluded that the "goals and intentions of the Church are directed against the very premise of the IRPA."143

\section{The Meaning of the Sign and Symbols in the Context of the Aryan Fest}

The Board found that the climate of the Aryan Fest, which they termed as a "celebration of racial intolerance," intensified the meaning of the sign and symbols. There was an impression of a national and international conspiracy to discriminate and encouragement of others to discriminate against Jewish and non-White persons.

The Board further stated that the sign and symbols used at the Aryan Fest were "far more powerful indications of discrimination"144 than those used in the other cases the Board had considered.

The Board's next task involved the determination of whether the discrimination was "for any purpose" 145 - the Board had to decide whether a display is prohibited only if it has to do with matters protected in the IRPA, such as employment or accommodation, or whether the section also prohibits displays which have to do with matters "not otherwise protected by the IRPA." Because there were no prior decisions interpreting the section, the Board was compelled to look to other provincial human rights statutes and their interpretation for assistance. 
The Board first looked at the Konyk ${ }^{146}$ case. As noted earlier, this case examined section 2(1) of the B.C. Human Rights Code and found that it did not create a substantive offence. The Board found that the difference in wording between the two Acts $^{147}$ was sufficient to distinguish that case from the one at bar.

The Board went on to state that while the text of section 2(1) of the IRPA is not as restrictive as that of the B.C. Code, there is still the question of constitutional jurisdiction. The Board held that they were staying within provincial jurisdiction in only looking at whether the sign and symbols used at the Aryan Fest "indicated discrimination or an intention to discriminate." Further, the Board examined the platform of the church, and determined that while some of the issues arising from the platform could be viewed as coming within federal jurisdiction, there were also many matters coming within provincial competence. The Board held that section 2(1) of the IRPA applied to matters not otherwise prohibited by the Act, but qualified this by stating that "any such matters must be within provincial legislative competence." ${ }^{148}$

The next issue analyzed by the Board was whether there was interference with "free expression on any subject." Section 2(2) of the IRPA provides:

Nothing in this section shall be deemed to interfere with the free expression of opinion on any subject.

Based on the recent Supreme Court opinion in Taylor, the Board interpreted this "exemption" clause to be an "'admonition' to 'balance' the necessity for 'eradicating discrimination with the need to protect free expression.'" 149 Since the Board could find no guidance in the IRPA itself as to how to balance these competing interests, they adopted the Oakes test. The Board stated that section 2(2) may not require an analysis as extensive or elaborate as the Oakes test, and that all that may be required is a statement that the Respondents' freedom of expression was considered in the making of the order. However, out of an "abundance of caution," the Board decided to employ "the more rigorous analysis of the Oakes test."150 The Board stated that even if they "had the duty of developing a method of analysis [they] would borrow heavily from the model developed in Oakes." ${ }^{\text {"sI }}$

In the first branch of the Oakes test, the Board determined that the objective of the $I R P A$ is the promotion of equality in the dignity and rights of all persons without regard

Ukranian Canadian Professional \& Business Assn. of Vancouver v. Konyk, [1983] 6 W.W.R. 204 (B.C.S.C.) [hereinafter Konyk].

Section 2(1) of the B.C. Act provides:

No person shall publish or display before the public...a...sign or other representation indicating discrimination or an intention to discriminate against a person or class of persons in any manner prohibited by this Act.

The fact that section 2(1) of the Alberta Act does not say "in any manner prohibited by this Act," in the Board's view, makes it less restrictive.

Supra note 127 at 89.

Ibid. at 92.

Ibid.

Ibid. at 94. 
to race, religion, colour, sex, physical disability, age, ancestry or place of origin. As for section 2(1) of the Act, the Board found that it had the same objective as that of hate propaganda prohibitions. The Board relied on Keegstra, Taylor and Andrews and Smith to find that the purpose of section 2 of the $A c t$ "is to stop discrimination which is the antithesis of the tolerance and open-mindedness necessary for the survival of our multicultural society." ${ }^{152}$ The Board further stated that

[i]f Parliament's objective in prohibiting hate propaganda is so pressing and substantial as to warrant the limitation of the fundamental freedom of expression, so too is the Province's objective in prohibiting signs and symbols which indicate discrimination or an intention to discriminate. ${ }^{153}$

In undertaking the proportionality analysis, the Board continued to rely on the reasoning of the Supreme Court of Canada in the above noted cases. The prohibition of discriminatory signs and symbols was held to be rationally connected to the goal of eradicating discrimination, in that the elimination of discriminatory displays should assist in reducing discrimination.

In the second branch of the proportionality test, the Board considered whether section 2(1) was more broad than necessary to meet its legislative objective. Again, the Board relied on Taylor to show that the section at issue was not overly broad. Concerns about the vague nature of words such as "hatred" and "contempt" were disposed of by the Court in Taylor, in stating that such problems should not arise as long as the interpretations of these words are fully informed by an awareness that Parliament's objective is to protect the equality and dignity of all individuals by reducing the incidence of harm-causing expression. ${ }^{154}$

The Board held that if concepts such as "hatred" and "contempt" did not present a problem of overbreadth, then neither did the concept of discrimination. According to the Board, the courts have had a wealth of experience in dealing with this concept and therefore it can be said to be well-defined.

Another issue addressed by the Board with respect to this branch of the Oakes test was the lack of an "intent" requirement in the section. Once again following the Supreme Court in Taylor, the Board held that the remedial and compensatory nature of human rights legislation (as opposed to the "stigmatization and punishment" focus of the criminal law) allows the absence of a requirement of intention without making the section overbroad.

Finally, the effects of the section were weighed against its objective and the Board held that they could find no basis upon which to disagree with the Supreme Court's reasons in Taylor since the reasoning in that case (as well as that in Keegstra and Andrews and Smith), corresponded to this case so closely. The Board found that the IRPA did not constitute an unacceptable restriction on freedom of expression. 
After dealing with two further issues, the Board detailed their findings and made some concluding observations. They stated that:

The Aryan Fest was a shocking event in the history of Alberta. The blatant display of signs and symbols redolent of racial and religious hatred, bigotry and discrimination challenge the very foundations of our society. ${ }^{155}$

The Board continued:

Multiculturalism is not a tentative notion or vague proposal for public policy. It is a legislated, constitutional concept. Similarly, equality between persons of different races, colours and religious beliefs is not a new concept open to debate. It is basic law. ${ }^{156}$

The Board further expressed concern that the Respondents they saw in the court room during the course of the proceedings felt extreme hatred toward Jews and nonWhites and that, given the chance, they would not hesitate to implement their plans. They were also concerned that these men and the organization they belong to did not appear to be alone in their ideologies. The Board went as far as to state that they felt there was a possibility of a conspiracy of international dimensions. The Board seemed most concerned about a possible recurrence of the Aryan Fest or a similar gathering and was also troubled about possible measures that might be taken by protesters or members of target groups in the event of another such occurrence:

The protestors at the 1990 Aryan Fest were armed only with picket signs. If another Aryan Fest were to be scheduled, exactly along the lines of the 1990 event, who can predict what the reaction of the protestors would be? How tolerant would the members of those groups targeted for hatred be the next time? Would they be content to submit to the bullying of the likes of Carney Nerland and Joey and Kelly Lyle? Would they be tempted to bring their own weapons for protection? This is more than a policing issue. ${ }^{157}$

\section{CONCLUDING REMARKS}

It is important for Canada to maintain criminal legislation sanctioning the promotion of hatred against minority groups. As stated by the majority in the Keegstra case, such legislation demonstrates the distaste of the public for hate propagandists and their message. Further, criminal sanctions confirm society's perception that minority groups are both in need of and deserving of protection against the harm caused by such messages. ${ }^{158}$ However, criminal sanctions prohibiting racist speech are not easily employed, and should not be applied indiscriminately. Criminal trials are time consuming and expensive and, because of exacting standards of proof, success is always in doubt. A concern arising out of this difficulty is that of the impact of an acquittal on

\footnotetext{
15s Supra note 127 at 107.

156 Ibid.

$157 \quad$ Ibid. at 109.
}

158 See J. Silverstone, "Why Canada needs to maintain its hate laws" 12:1 Intercom (Canadian Jewish Congress). 
a criminal charge of incitement to hatred; an unsuccessful prosecution may have the effect of lending validity to the contents of the hate literature itself.

Human rights legislation has some considerable advantages over criminal sanctions. Human rights hearings, while costly themselves, tend to be less time consuming and less expensive than criminal trials. It is easier to bring a complaint under human rights legislation than under the Criminal Code, since police are not required to lay a charge and the consent of the Attorney-General is not required in order for the Commission to proceed with an investigation. Also, unlike the Attorney-General who has discretion as to whether to proceed, the Human Rights Commission is obligated to take action once a complaint has been made. ${ }^{159}$ Another possible advantage is that the human rights process may be viewed as less intimidating to prospective complainants than the criminal process.

The standard of proof in a human rights inquiry is the civil standard: proof on a balance of probabilities. This requirement is much less stringent than the criminal burden of proof beyond a reasonable doubt. Further, there is no need to prove intent in a human rights inquiry, as there is in a criminal trial.

A major advantage of a human rights inquiry over a criminal trial is that there is correct "labelling". In a criminal trial, the defendant tends to be transformed into a martyr in that his human rights are the subject of public debate; he is contesting the state, an extremely powerful opponent. In human rights inquiries, on the other hand, the indication is (more accurately) that the hate-monger is the violator of rights. In criminal proceedings, the defendant will have been "prepared" by his attorney, so that he comes across as "composed, reflective, [and] intelligent," ${ }^{160}$ giving credence to his message. Further, the criminal trial procedural safeguards, such as evidentiary rules and the presumption of innocence, tend to lend dignity to the accused. ${ }^{161}$

The availability of appeals for technical reasons can result in the appearance of "social legitimation" ${ }^{162}$ or vindication of the accused's views if he is successful on appeal.

A panoply of provisions designed to combat rising racism is the most effective way for the state to deal with the problem. Customs and excise provisions can be used to prevent objectionable material from entering the country, while immigration policies can prevent known racists from disseminating their messages here. Finally, human rights statutes or criminal sanctions can be employed to show that Canadian society will not tolerate the promulgation of racist invective. By employing a combination of methods including public education, we will, hopefully, be able to combat the impact

For further discussion of the procedural advantages of Human Rights legislation, see Mahoney, supra note 117. 
of racist speech by minimizing the credibility of the hate-monger and the susceptibility of the community to his racist message, and in the process we will create a just, tolerant, and truly multicultural society.

AUTHOR'S NOTE: On the 7th of September, 1994, the Alberta Court of Appeal, by a 2-1 majority, overturned Keegstra's second jury conviction and ordered a new trial. This decision was based upon alleged errors in the judge's conduct of the trial. At press time, the Attorney-General of Alberta had not yet decided whether to appeal the matter to the Supreme Court of Canada, commence a third prosecution of Keegstra, or leave matters as they stand. 